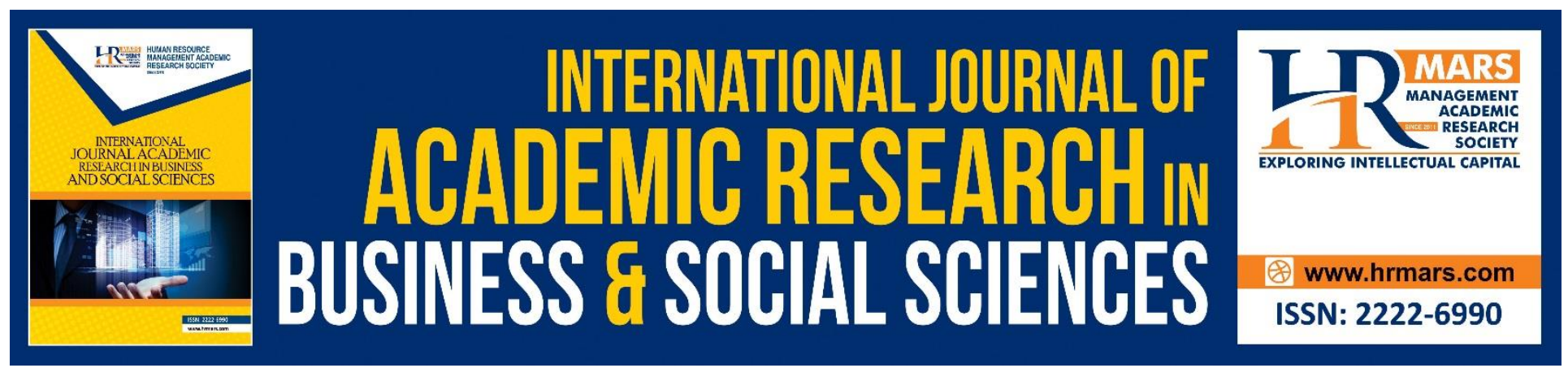

\title{
Linking Dynamic Capability and Innovation Strategy to Social Enterprise Performance: A Conceptual Model
}

\author{
Erne Suzila Kassim, Thareq Ariffin Mohd Tajmi, Naffisah Mohd Hassan and \\ Siti Uzairiah Mohd Tobi
}

To Link this Article: http://dx.doi.org/10.6007/IJARBSS/v8-i12/5286

DOI: $10.6007 /$ IJARBSS/v8-i12/5286

Received: 28 Oct 2018, Revised: 11 Dec 2018, Accepted: 21 Dec 2018

Published Online: 30 Dec 2018

In-Text Citation: (Kassim, Tajmi, Hassan, \& Tobi, 2018)

To Cite this Article: Kassim, E. S., Tajmi, T. A. M., Hassan, N. M., \& Tobi, S. U. M. (2018). Linking Dynamic Capability and Innovation Strategy to Social Enterprise Performance: A Conceptual Model. International Journal of Academic Research in Business and Social Sciences, 8(12), 1663-1670.

\section{Copyright: (c) 2018 The Author(s)}

Published by Human Resource Management Academic Research Society (www.hrmars.com)

This article is published under the Creative Commons Attribution (CC BY 4.0) license. Anyone may reproduce, distribute, translate and create derivative works of this article (for both commercial and non-commercial purposes), subject to full attribution to the original publication and authors. The full terms of this license may be seen

at: $\underline{\text { http://creativecommons.org/licences/by/4.0/legalcode }}$

\section{Vol. 8, No. 12, 2018, Pg. 1663 - 1670}

Full Terms \& Conditions of access and use can be found at http://hrmars.com/index.php/pages/detail/publication-ethics 


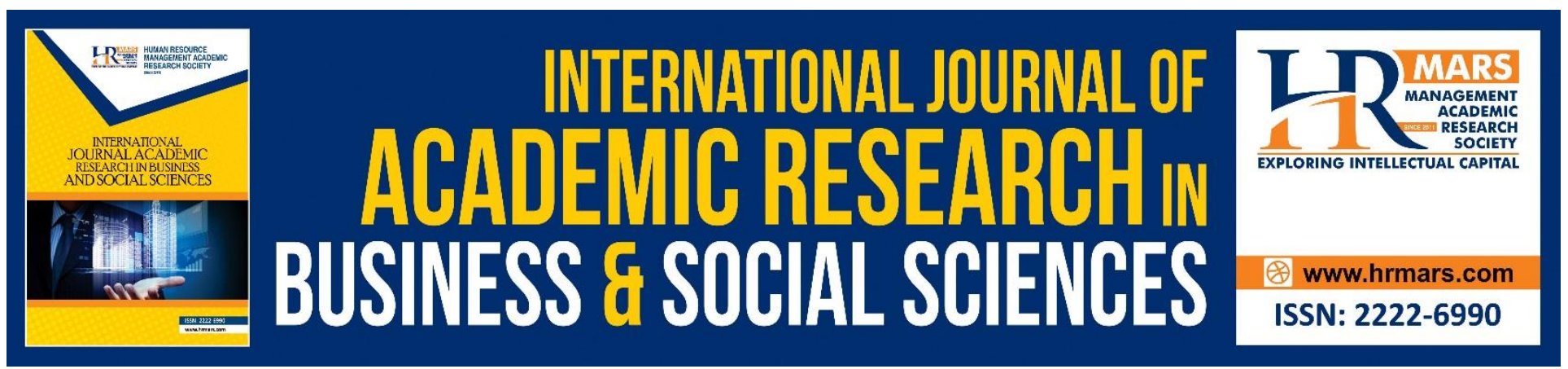

\title{
Linking Dynamic Capability and Innovation Strategy to Social Enterprise Performance: A Conceptual Model
}

\author{
${ }^{1}$ Erne Suzila Kassim, ${ }^{1}$ Thareq Ariffin Mohd Tajmi, ${ }^{1}$ Naffisah Mohd \\ Hassan and ${ }^{2}$ Siti Uzairiah Mohd Tobi \\ ${ }^{1}$ Faculty of Business and Management, Universiti Teknologi MARA Cawangan Selangor, \\ Kampus Puncak Alam, 42300, Selangor, MALAYSIA \\ ${ }^{2}$ RAZAK School of Engineering and Advanced Technology, Universiti Teknologi Malaysia \\ Corresponding Author Email: ${ }^{1}$ ernekassim@puncakalam.uitm.edu.my
}

\begin{abstract}
In this paper, we offer a conceptual model for social enterprise (SE) performance that emphasizes on the roles of dynamic capabilities and innovation strategies. SE is vital as the third sector economy that addresses on the social, economic and environment agenda. Studying the phenomena of social entrepreneurship and explaining the social enterprises' unique behaviors, characteristics, and typologies will advance research for creating sustainable public wealth. The model offers an opportunity for evaluation and validation through variety of research design and settings, and could be of interest to many. Ultimately, it could be used to quantify the contributions of social enterprises as the third sector economy.
\end{abstract}

Keywords: Social Enterprise, Social Enterprise Performance, Third Sector Economy, Dynamic Capability, Innovation Strategy

\section{INTRODUCTION}

On a global scale, the world is ageing that most likely, it puts the public budgets on education, health, environment agenda and welfare including dealing with social exclusion and poverty under pressure. To address the critical situation, the third sector economy, also known as the social economy that engages all sectors of the society is well positioned (Defourny et al. 2014). The remarkable growth of social enterprises (SE) that belong neither "to the traditional private for-profit sector nor to the public sector" (Defourny et al. 2001) signifies the importance of the socio-economic initiatives as the third sector. Social enterprise is an alternative type of business strategy drawing upon elements of entrepreneurship (Defourny et al. 2001), which is established with the main agenda of creating 
positive social change and social values (Auvinet and Lloret 2011). Examples of social enterprise initiatives include provisions of jobs creations and community programs for the indigenous (Spencer et al. 2016), disable individuals (Luke et al. 2013) and work integration social enterprise (WISE) (Bagnoli and Megali 2011).

However, maintaining a social enterprise establishment is very challenging. Running the enterprise as a voluntary organization, with limited funds and complex governance relationships requires dynamic strategies for its success continuance. As social enterprises are reflected as private activities conducted in and with public interest (Ngonini 2014), which seek to serve the community's interest rather than profit maximization (Pisano et al. 2015), the social enterprise's innovation capability and ability to sustain funds are essential. However, the exploration on how social enterprise's innovation capability will drive the performance require further understanding. Innovation strategy and organizational innovation have become the focus of many organizational studies, as evident in the work of Jajja at al. (2017), Rousseau at al. (2016) and Crossan and Apaydin (2010). In addition, how dynamic capabilities are important for enterprise performance has been explicitly discussed (Teece et al. 1997). Yet, how the two could assist in conceptualizing the social enterprise performance has not been discussed in depth. Hence, in this paper, we propose a model of social enterprise performance towards the third sector economy success by focusing on the essence of dynamic capability and innovation strategy.

\section{SOCIAL ENTERPRISE AND PERFORMANCE}

Social entrepreneurship was introduced in the 1970s to address the issue of social problems sustainably (El Ebrashi 2013) and it was first mentioned in 1972 by Joseph Banks in his seminal work named The Sociology of Social Movements. Since then, social enterprises have been used extensively to define works related to "process involving the innovative use and combination of resources to pursue opportunities to catalyze social change and/or address social needs" (Hausmann 2015). Although there are different types of social enterprises, Milligan (2013) outlined SE based on profit/nonprofit-orientation and sources of funds which draw into three major categories; 1) Leveraged non-profits, 2) Hybrid non-profit ventures and 3) Social business ventures.

Likewise, how social enterprise measure its performance could be evaluated from the aspects of three characteristics of triple-bottom line, which are economic, social and environment. The economic bottom line deals with the economic benefits enjoyed by the host society, which includes socio-economic improvement. However, most studies measured the economic aspects as financial and organizational performance, and stakeholder relationship (Bastida et al. 2017; Kim and Moon 2017; Miles et al. 2013). Similarly, the social bottom line is the social equity and social values. They could be measured as sustaining the quality of life and social ecology (Spencer et al. 2016; Miles et al. 2013), health and education improvement (Arogyaswamy 2017) and provision of access to work (Cho and Kim 2017). Finally, the environment ecology is the benefits to the natural capital and could be measured as the impacts to social relationships (Miles et al. 2013) and energy consumption (Arena et al. 2015). 
INTERNATIONAL JOURNAL OF ACADEMIC RESEARCH IN BUSINESS AND SOCIAL SCIENCES

Vol. 8, No. 12, Dec, 2018, E-ISSN: 2222-6990 @ 2018 HRMARS

\section{DYNAMIC CAPABILITY AND SOCIAL ENTERPRISE PERFORMANCE}

Dynamic capability is an organization's "ability to integrate, build, and reconfigure internal and external competencies to address rapidly-changing environments" (Teece et al. 1997). Dynamic capability is well suited to be applied and emphasized in social enterprise context as the microfoundation focuses on the distinct skills, processes, procedures, structures, rules and disciplines. Figure 1 illustrates the dynamic capability and how the elements interact to each other, which is adopted from (Teece et al. 1997).

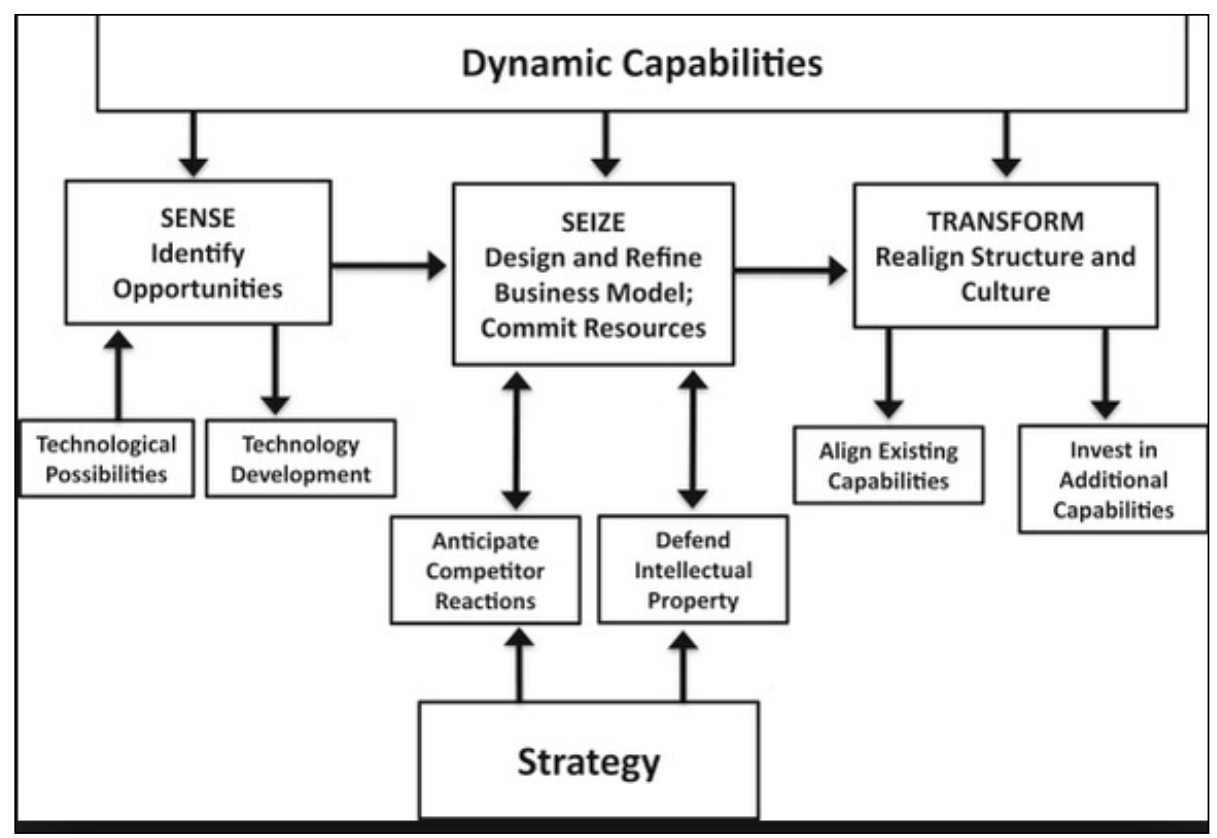

Figure 2. Dynamic Capability and Its Elements (Teece et al. 1997)

Teece (2007) believed successful enterprises are intensely dynamic capable and able "(a) to sense and shape opportunities and threats, (b) to seize opportunities, and (c) to maintain competitiveness through enhancing, combining, protecting, and, when necessary, reconfiguring the business enterprise's intangible and tangible asset". However, with the rapid development of technology and how it changes the socio-economic landscape of social enterprise, technological capabilities should also be captured. Hence, as emphasized by (Shuen and Sieber 2009), digital competencies and network economics must be taken into account. Therefore, as social enterprises must survive the changing social, economic and environmental needs, the ability to sense and seize opportunities, and to maintain competitiveness is upmost important.

\section{INNOVATION STRATEGY AND SOCIAL ENTERPRISE PERFORMANCE}

The role of social entrepreneurs in the third sector economy is very challenging. Leveraging social networks, assembling resources and bridging institutional voids as according to Pisano (2015) require collective actions and continuous innovative strategies. Without an innovation strategy, innovation 
INTERNATIONAL JOURNAL OF ACADEMIC RESEARCH IN BUSINESS AND SOCIAL SCIENCES

Vol. 8, No. 12, Dec, 2018, E-ISSN: $2222-6990$ @ 2018 HRMARS

improvement efforts can easily become "a grab bag of much-touted best practices" (Pisano 2015). Looking at the nature of social enterprise, four characteristics of innovation strategies are fundamental. These are service/product innovation, process innovation, management innovation and marketing innovation.

\section{Product/Service Innovation Strategy and SE Performance}

Product or service innovations are the introduction of a new creation to meet an external user or the market needs (Damanpour and Aravind 2012). While research on product/service innovations often focus on large and medium size organizations, effort has been made by (Verhees and Meulenberg 2004) to examine the effects of product innovation to small enterprises' performance. The results indicate innovativeness has a strong influence to performance. Recent findings also conclude product innovation is the determinant of organizational performance (Jajja et al. 2017). Hence, product/service innovations should be regarded as important criteria in sustaining social enterprise.

\section{Process Innovation Strategy and SE Performance}

Viewing innovation as a process means addressing "how" rather than "what" or "how many" (Crossan and Apaydin 2010). It could be categorised based on levels of analysis, internal, and external drivers. Viewing the levels of analysis, process innovation can be examined at the levels of individual, group, organizational, and at the population or inter-organization. Next, the internal drivers include direction, which relates to top-down versus bottom-up processes; source or inspiration for ideas stemming from internal, external and locus, which refers to space of innovation such as closed (within firm) versus open (or networked) processes. Finally, the external drivers can include influences stemming from markets or regulation (Crossan and Apaydin 2010). Rousseau et al. (2016) concluded the integration of both product and process innovations yield stronger performance gains. Thus, process innovation should be included as an important determinant of SE performance.

\section{Management Innovation Strategy and SE Performance}

Management innovation is a form of process innovation that is considered non-technological and influential in impacting success measures (Černe et al. 2013). Based on Damanpour and Aravind (2012), management innovation encompasses processes that lead to change in strategy, structure, administrative processes, and systems. It positions managerial innovation as new organizational structures, administrative systems, management practices, processes and techniques that could create value for the organization, and is considered very important. In the context of social enterprise, having good relationships with multi stakeholders is the key to success. Kim and Moon (2017) concluded managerial capacity is an antecedent of social enterprise performance. Hence, community relationship, relationship governance and partner selection must be addressed adequately.

\section{Marketing Innovation Strategy and SE Performance}

Marketing strategy is the initiative that dwells into the branding, low-cost and channel strategy (Hsu 2011). From this perspective, marketing strategy and product innovation are closely linked. Even though the marketing innovation strategy was not extensively studied in social enterprise 
INTERNATIONAL JOURNAL OF ACADEMIC RESEARCH IN BUSINESS AND SOCIAL SCIENCES

Vol. 8, No. 12, Dec, 2018, E-ISSN: 2222-6990 @ 2018 HRMARS

research, Liu and Takeda (2015) found the evidences that marketing capabilities and marketing orientation predict both social and economic performances of social enterprises. Therefore, it is crucial to address the marketing strategies appropriately for sustaining the social involvement.

\section{CONCEPTUAL MODEL AND CONCLUSION}

Based on the discussion, we offer a model that captures the importance of dynamic capability and innovation strategies as factors of social enterprise performance. How they interact is depicted in Figure 2. Studying the phenomena of social entrepreneurship and explaining the social enterprises' unique behaviors, characteristics, and typologies will advance research for creating sustainable public wealth (El Ebrashi, 2013). Social entrepreneurship and innovation are pivotal to unlocking growth and economic inclusion.

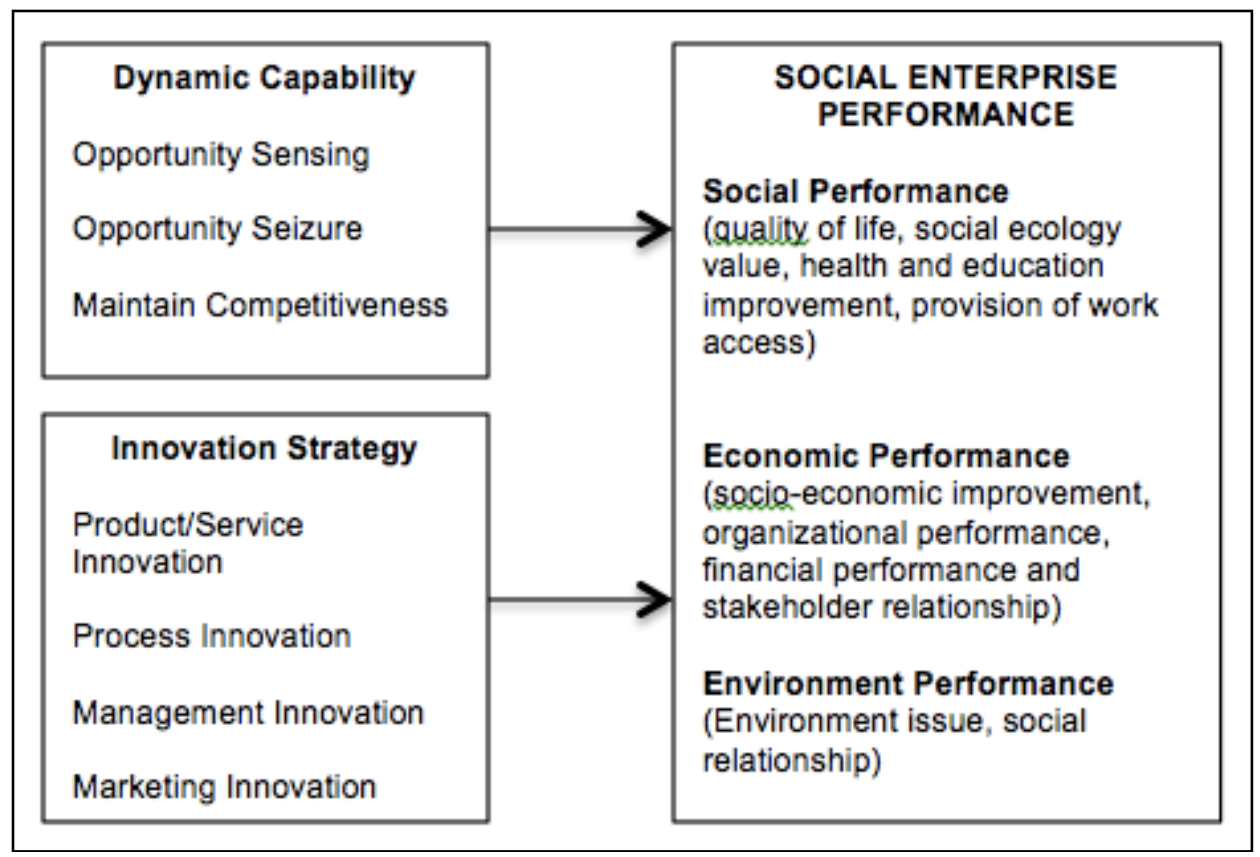

Figure 2. A Conceptual Model of Social Enterprise Performance

As a conclusion, this model offers an opportunity for evaluation and validation through variety of research design and settings. The proposed model should be of interests to social entrepreneurs, donors and beneficiaries, local stakeholder and communities, and government agencies. Ultimately, it could be used to quantify the contributions of social enterprises as the third sector economy.

\section{Acknowledgements}

The authors gratefully acknowledge the help of Universiti Teknologi MARA in providing the Research Grant Scheme Fund (Project Number: 600-IRMI/MyRA 5/3/BESTARI (007/2017)) and Faculty of Business and Management for supporting the research work.

\section{References}

Arena, M., Azzone, G., \& Bengo, I. (2015). Performance measurement for social enterprises. VOLUNTAS: International Journal of Voluntary and Nonprofit Organizations, 26(2), 649-672. 
INTERNATIONAL JOURNAL OF ACADEMIC RESEARCH IN BUSINESS AND SOCIAL SCIENCES

Vol. 8, No. 12, Dec, 2018, E-ISSN: $2222-6990$ C 2018 HRMARS

Arogyaswamy, B. (2017). Social entrepreneurship performance measurement: A time-based organizing framework. Business Horizons, 60(5), 603-611.

Auvinet, C., \& Lloret, A. (2011). Catalytic innovation as a strategy for social change and economical success. The case of Mexico. Cuadernos de Estudios Empresariales, 21, 115.

Bagnoli, L., \& Megali, C. (2011). Measuring performance in social enterprises. Nonprofit and Voluntary Sector Quarterly, 40(1), 149-165.

Bastida, R., Bastida, R., Marimon, F., Marimon, F., Tanganelli, D., \& Tanganelli, D. (2017). Alliance success factors and performance in social economy enterprises. Management Decision, 55(5), 1065-1080.

Černe, M., Jaklič, M., \& Škerlavaj, M. (2013). Decoupling management and technological innovations: Resolving the individualism-collectivism controversy. Journal of International Management, 19(2), 103-117.

Cho, S., \& Kim, A. (2017). Relationships Between Entrepreneurship, Community Networking, and Economic and Social Performance in Social Enterprises: Evidence from South Korea. Human Service Organizations: Management, Leadership \& Governance, 1-13.

Crossan, M. M., \& Apaydin, M. (2010). A multi-dimensional framework of organizational innovation: A systematic review of the literature. Journal of management studies, 47(6), 1154-1191.

Damanpour, F., \& Aravind, D. (2012). Managerial innovation: Conceptions, processes and antecedents. Management and organization review, 8(2), 423-454.

Defourny, J., Borzaga, C., \& Defourny, J. (2001). From third sector to social enterprise (pp. 1-28). London: Routledge.

Defourny, J., Hulgård, L., \& Pestoff, V. (Eds.). (2014). Social enterprise and the third sector: Changing European landscapes in a comparative perspective. Routledge.

El Ebrashi, R. (2013). Social entrepreneurship theory and sustainable social impact. Social Responsibility Journal, 9(2), 188-209.

Hausmann, R. C. (2015). Organizing Ecosystems for Social Innovation: The Relationality of Contexts and Mechanisms in a Social Entrepreneurship Network (Doctoral dissertation, The George Washington University).

Hsu, Y. (2011). Design innovation and marketing strategy in successful product competition. Journal of Business \& Industrial Marketing, 26(4), 223-236.

Jajja, M. S. S., Kannan, V. R., Brah, S. A., \& Hassan, S. Z. (2017). Linkages between firm innovation strategy, suppliers, product innovation, and business performance: insights from resource dependence theory. International Journal of Operations \& Production Management, 37(8), 1054-1075.

Kim, T. H., \& Moon, M. J. (2017). Using Social Enterprises for Social Policy in South Korea: Do Funding and Management Affect Social and Economic Performance?. Public Administration and Development, 37(1), 15-27.

Liu, G., Eng, T. Y., \& Takeda, S. (2015). An investigation of marketing capabilities and social enterprise performance in the UK and Japan. Entrepreneurship Theory and Practice, 39(2), 267-298. 
INTERNATIONAL JOURNAL OF ACADEMIC RESEARCH IN BUSINESS AND SOCIAL SCIENCES

Vol. 8, No. 12, Dec, 2018, E-ISSN: $2222-6990$ C 2018 HRMARS

Luke, B., Barraket, J., \& Eversole, R. (2013). Measurement as legitimacy versus legitimacy of measures: Performance evaluation of social enterprise. Qualitative Research in Accounting \& Management, 10(3/4), 234-258.

Miles, M. P., Verreynne, M. L., Luke, B., Eversole, R., \& Barraket, J. (2013). The relationship of entrepreneurial orientation, Vincentian values and economic and social performance in social enterprise. Review of Business, 33(2), 91.

Milligan, K. (2013). Breaking the Binary: Policy Guide to Scaling Social Innovation. Cologny: Schwab Foundation for Social Entrepreneurship.

Ngonini, X. (2014). Mapping out the role of social entrepreneurship and innovation in economic growth and job creation: A case of a state-owned entity in South Africa. In International Conference on Management, Leadership \& Governance (p. 406). Academic Conferences International Limited.

Pisano, G. P. (2015). You need an innovation strategy. Harvard Business Review, 93(6), 44-54.

Pisano, U., Lange, L., \& Berger, G. (2015). An overview of the concept of social innovation in the context of European initiatives and practices. European Sustainable Development Network

Rousseau, M. B., Mathias, B. D., Madden, L. T., \& Crook, T. R. (2016). Innovation, firm performance, and appropriation: A meta-analysis. International Journal of Innovation Management, 20(03), 1650033.

Shuen, A., \& Sieber, S. (2009). Orchestrating the new dynamic capabilities. IESE Insights, Fourth Quarter, 3, 58-65.

Spencer, R., Brueckner, M., Wise, G., \& Marika, B. (2016). Australian indigenous social enterp rise: measuring performance. Journal of Enterprising Communities: People and Places in the Global Economy, 10(4), 397-424.

Spencer, R., Spencer, R., Brueckner, M., Brueckner, M., Wise, G., Wise, G., ... \& Marika, B. (2016). Australian indigenous social enterprise: measuring performance. Journal of Enterprising Communities: People and Places in the Global Economy, 10(4), 397-424.

Teece, D. J. (2007). Explicating dynamic capabilities: the nature and microfoundations of (sustainable) enterprise performance. Strategic management journal, 28(13), 1319-1350.

Teece, D. J., Pisano, G., \& Shuen, A. (1997). Dynamic capabilities and strategic management. Strategic management journal, 18(7), 509-533.

Verhees, F. J., \& Meulenberg, M. T. (2004). Market orientation, innovativeness, product innovation, and performance in small firms. Journal of small business management, 42(2), 134-154. 